\title{
LA NUMANCIA CERVANTINA. HACIA UNA POÉTICA MODERNA DE LA EXPERIENCIA TRÁGICA
}

Todas las interpretaciones de lo trágico resultan insuficientes.

K. JASPERS ${ }^{1}$

\section{INTRODUCCIÓN}

Con la llegada de la Edad Moderna la tragedia pierde muy sensiblemente sus implicaciones metafísicas; la presencia de lo sobrenatural y numinoso no se niega, ni mucho menos se descarta, pero se atenúa. La inferencia metafísica deja de percibirse con nitidez. Hamlet no está sólo en su visión del espectro, pero sí es el único que oye sus voces. El Escipión que pinta Cervantes en la Numancia advierte desde el principio a sus soldados que en este mundo «cada cual se fabrica su destino», y que "no tiene aquí Fortuna alguna parte» (I, 57-58). La Edad Moderna habla de los dioses, pero no dialoga con ellos. Hereda una mitología procedente del mundo antiguo, una mitología que recrea y rememora, pero que no le pertenece, y con la que no puede identificarse plenamente, pues el cristianismo ha introducido su propia y disciplinada estructura mítica, a través de una metafísica mucho más contundente, desde la cual se apunta hacia un orden religioso en el que sólo se reconocen valores morales.

En este contexto, el teatro de Miguel de Cervantes constituye un eslabón decisivo, desde el punto de vista de la evolución de la dramaturgia occidental, en sus formas trágicas y en sus formas cómicas, hacia una concepción moderna y contemporánea tanto del personaje teatral (sujeto) como de la acción dramática (fábula) que desarrolla. Cervantes, movido acaso por la falsa convicción perso-

1 Cfr. K. JASPERS (1948), Über das Tragische. Die Sprache en Von der Wahrheit. Philosophische Logik. München-Zurich, Erster Band, 1991. Trad. esp. de J. L. DEL BARco, Lo trágico. El lenguaje. Málaga, Agora, 1995, p. 65. 
nal de estar más próximo a Aristóteles que el propio Lope de Vega - creencia que ha perdurado todavía en algunos lectores de la segunda mitad del siglo $\mathrm{xx}$-, construye una obra literaria que está mucho más cerca, en sus planteamientos estéticos y axiológicos, de cualquier tendencia de la poética moderna que de toda la teoría literaria de la Antigüedad clásica, de la que se sirve con intensidad, precisamente porque la supera en capítulos decisivos de la formación de la literatura y de la teoría literaria modernas, como los relacionados con el tratamiento del decoro y la polifonía, de la presencia formal y funcional del sujeto en la fábula, del orden moral trascendente desde el que el protagonista justifica sus formas de conducta, de la experiencia subjetiva del personaje, o de la construcción de figuras literarias que superan todos los arquetipos posibles de su tiempo.

Tal como ha sido configurado a lo largo de la tradición occidental, el concepto de tragedia está determinado desde Aristóteles ${ }^{2}$ por características muy concretas, sobre las que han podido influir diferentes realizaciones literarias. En primer lugar, la experiencia trágica es, en su sentido genuino y helénico, la experiencia de un sufrimiento $^{3}$. En segundo lugar, es de advertir que en todo hecho trágico subyace, con mayor o menor intensidad, una inferencia metafísica, una implicación en una realidad trascendente a lo humano, y que lo meramente humano no puede explicar ni interpretar de forma absoluta o definitiva. En cierto modo, la tragedia no tiene sentido si no existe una amenaza posible después de la muerte. En tercer lugar, para que un hecho cualquiera pueda alcanzar en nuestra conciencia la expresión de hecho trágico es absolutamente imprescindible una acción voluntaria por parte del ser humano.

\footnotetext{
2 «Es, pues, la tragedia, imitación de una acción esforzada y completa, de cierta amplitud, en lenguaje sazonado, separada cada una de las especies [de aderezos] en las distintas partes, actuando los personajes y no mediante relato, y que mediante compasión y temor lleva a cabo la purgación de tales afecciones" (ARISTÓTELES, Poética, 1449 b 24-28). Seguimos la edición trilingüe de V. García Yebra. Madrid, Gredos, 1992 (1. ${ }^{\mathrm{a}}$ ed., 2. ${ }^{\mathrm{a}}$ reimpr.)

3 F. NIETZSCHE (1871) consideraba que el efecto de la tragedia antigua se basaba esencialmente en la idea del sufrimiento y del padecimiento, así como en el acto de su percepción, consumando de este modo el patetismo, como contemplación del dolor, antes que en la construcción de una fábula o acción, más o menos enigmática, cuya intriga, causas y relaciones, hubieran de ser resueltas por el entendimiento. El origen de la tragedia estaría en la experiencia del sufrimiento y de lo patético; sólo con el pensamiento socrático se pasa a la percepción cognoscitiva, a lo apolíneo, a la reflexión sobre la idea frente al sentimiento. En consecuencia, Eurípides representa para Nietzsche el dramaturgo más socrático del mundo griego, frente a Esquilo, en cuya obra identifica el logro de los valores trágicos en su expresión más genuina. Vid. F. NIETZsCHE, Die Geburt der Tragöedie. Leipzig, 1871; trad. esp. de A. IzQuiERDo, El nacimiento de la tragedia. Barcelona, Edaf, 1998.
} 
El hombre ha de actuar, en principio libre y voluntariamente, y con su acción ha de provocar un conflicto que, merced a la causalidad de los hechos, desemboca en la destrucción de la existencia. En cuarto lugar, hallamos que en toda acción trágica subyace una cita con el conocimiento y sus límites. La verdad es más intensa que el mero conocimiento: la verdad que justifica la tragedia es superior e irreductible al conocimiento humano, lo trasciende y lo supera, haciendo inexplicable la causalidad de los hechos ${ }^{4}$. En quinto lugar, podría señalarse que toda experiencia trágica tiene su origen más primitivo en alguna forma de protesta y rebeldía. La tragedia es expresión de un sacrificio humano, que se esgrime como protesta ante condiciones extremas de opresión que ahogan o limitan la vida de los hombres. En sexto lugar, conviene considerar uno de los atributos esenciales del sufrimiento que la realidad trascendente impone al protagonista del hecho trágico: el castigo. Los acontecimientos trágicos se suceden de forma inexorable, y ante la incapacidad humana para explicar y justificar su causalidad, se perciben como absurdos. En séptimo lugar, finalmente, no podemos olvidarnos del lenguaje. Todo cuanto sucede en la tragedia sucede dentro del lenguaje. La acción trágica se objetiva esencialmente en las palabras ${ }^{5}$.

Aristóteles había definido la tragedia por su finalidad, que identificaba como sabemos en la purgación o purificación de las pasiones mediante los sentimientos de piedad y temor, a través de los cuales el espectador alcanzaba una experiencia catártica. Aunque no resulta completamente claro qué sentido quiso dar Aristóteles a este término (alquimia, purgación, purificación...), parece que en la obra trágica, tal como el autor griego entiende la catarsis, deben darse determinadas condiciones. Entre estos requisitos Aristóteles advierte que los personajes de la tragedia no deben ser ni absolutamente buenos ni absolutamente malos (Poética, 1452 b-1453 a), e insiste en que a través del sentimiento de la piedad el espectador partici-

4 Este es el pensamiento helénico sobre la tragedia; el judaísmo, sin embargo, considera, de forma muy semejante al cristianismo, que existe una clarísima relación racional y directa entre la acción humana y sus posibilidades de conocimiento. Para el mundo griego, la distancia entre acción y conocimiento constituye un "abismo irónico». Cfr. G. STEINER (1961), The Death of Tragedy. New York, Knopf. Reeditado en Oxford University Press, 1981. Trad. esp. de E. L. REVOL, La muerte de la tragedia. Caracas, Monte Ávila, 1991, pp. 12 ss.

5 La acción total se da dentro del lenguaje, y todo salvo el lenguaje del ser humano es en la tragedia economía de medios. El verso fue prácticamente hasta la Edad Contemporánea el discurso de la tragedia; el uso de la prosa es relativamente reciente, y en cierto modo está asociado a las formas que conducen a su decadencia. En buena medida el verso representa para la tragedia la forma clásica; la prosa, su forma abierta. 
pa del sufrimiento del héroe, a la vez que a través del horror que suscita el hecho trágico el mismo espectador se imagina víctima potencial de los infortunios representados en el escenario ${ }^{6}$. Ambas emociones, temor y piedad, surgen o resultan de un mismo proceso, el de la identificación del espectador con el personaje.

El teatro de Cervantes, al menos en su tragedia Numancia, se distancia sensiblemente de una ordenación teleológica de tales características. En primer lugar, porque en su tragedia hay personajes, como los numantinos, que no parece hayan cometido ningún error o falta moral, hybris lo denominaban los griegos, que haga justificable, o explicable desde ese punto de vista, la desgracia que sufren; acaso es más bien Escipión quien incurre en un momento dado en el exceso o "desmesura» que motiva la tragedia, pues al rechazar la embajada numantina, que pretende la paz con los romanos a cambio de la justicia de sus cónsules, precipita la autoinmolación de todo un pueblo. Un personaje detenta siempre el poder en el momento de la desgracia. Un desliz, una desmesura, un exceso irreversible (hybris), en el ejercicio del poder, desencadena siempre una desolación irreparable. No son en este caso los arévacos quienes incurren en estos excesos, sino Escipión. Los numantinos pasan, inocentemente, de la dicha al infortunio, e inspiran en el espectador piedad y temor, y nunca "repugnancia», contrariamente a lo que debía suceder en situaciones de este tipo según las exigencias de la poética clásica, tal como había advertido Aristóteles con toda claridad en su teoría sobre la tragedia: «es evidente que ni los hombres virtuosos deben aparecer pasando de la dicha al infortunio, pues esto no inspira ni temor ni compasión, sino repugnancia; ni los malvados, del infortunio a la dicha” (Poética, 13, 1452b 35-36) ${ }^{7}$. ¿Qué hay de particular, pues, en la experiencia trágica de la $\mathrm{Nu}$ -

6 Nos interesa insistir desde este momento en el hecho de que Aristóteles caracterizara la tragedia, frente a la acción y las figuras propias de la comedia, por la dignidad de su tema y la nobleza estamental de sus personajes. Es este uno de los aspectos de la teoría de Aristóteles más ampliamente comentados por EsCALígero, en su Poetica (libro I, cap. 4) de 1561, y más claramente asumido por todos los preceptistas de la Edad Moderna. El teatro cervantino, especialmente en la tragedia Numancia, se distancia formal y funcionalmente de este imperativo, al presentar como protagonistas de la experiencia trágica a personajes de condición humilde, si bien capaces de hechos heroicos, y dotados, como los antiguos héroes de la Grecia clásica, de un carácter capaz de expresar la dignidad del dolor y la piedad del sufrimiento, lo cual hace aún más controvertida su presencia en la tragedia.

7 Teóricos y dramaturgos seguidores del clasicismo, especialmente de orientación francesa, atribuyeron a la tragedia las mismas funciones que señalaba Aristóteles, y lo hicieron en dos direcciones, al identificar la catarsis trágica con la interpretación moralista, que trataba de configurar una literatura dramática como expresión moral para el hombre (Bérénice, de J. RACINE; Ars poétique, de N. BoIlEAU, canto III, vs. 5-8), y con la interpretación mitridática, en virtud de la cual la con- 
mancia cervantina, que sin negar la autoridad del clasicismo aristotélico no se adecua ni formal ni funcionalmente a muchos de sus imperativos esenciales? Una tentativa de modernidad distancia la creación literaria cervantina de la poética clásica del Renacimiento, y quizá aún más intensamente del aristotelismo desde el que se explica y fundamenta el mundo antiguo.

\section{LA POÉTICA DE LO TRÁGICO EN LA NUMANCIA}

La Numancia constituye una tragedia que reflexiona sobre las posibilidades del ejercicio de la libertad humana en circunstancias extremas de impotencia, individual y colectiva, para su desarrollo, es decir, de incapacidad para actuar en libertad, al carecer el sujeto completamente de facultades de poder (posibilidad), en una situación en la que, de forma muy dramática, el ser humano sigue conservando exacerbadamente tanto el deseo de acción (voluntad) como las capacidades de conocimiento y reflexión (saber) necesarias para actuar. La Numancia es en este sentido la expresión trágica de una impotencia humana suprema, ante todo consciente de sí misma, y que con toda la fuerza de su voluntad se enfrenta a una realidad superior e inderogable, de naturaleza igualmente humana, que ha de negar en el adversario, hasta destruirla absolutamente, toda posibilidad de vida. Tragedia de imposibilidades vitales, de conocimiento de los hechos y de ansia de libertad por encima de cualquier limitación sobre la existencia humana, la Numancia dignifica el sufrimiento del sujeto individual y colectivo, a la vez que confiere un reconocimiento, inédito hasta entonces en el género, a los sentimientos aristotélicos de horror y piedad en la experiencia vital de las gentes humildes, a las que instituye en protagonistas del hecho trágico. Sólo gentes humildes defienden en la Numancia la libertad humana, a la vez que dignifican el dolor que inspira su propia compasión.

\subsection{El decoro de los humildes}

Los numantinos, protagonistas de la experiencia trágica, no son personajes aristocráticos, ni están representados en la acción de la tragedia desde el amparo de ninguna institución o estructura nobiliaria. Se rompe así con los imperativos del decoro propios de la tragedia clásica, desde la que se exigía que el protagonismo de la experiencia trágica recayera sobre personajes de condición noble 0 aristocrática ${ }^{8}$.

templación de la tragedia representa para el ser humano una preparación capaz de hacer frente a posibles infortunios.

8 E. Auerbach ha recordado en su Mímesis (1942) una idea decisiva que 
Los dos numantinos que constituyen la embajada desde la que se propone la paz a Escipión no se presentan con nombre propio, ni esgrimen un estamento social o estructura aristocrática en nombre de la cual representen a la totalidad de su pueblo, sino que simplemente se declaran «ciudadanos» de Numancia, y se denominan respectivamente "primero» y "segundo». Reconocen la dignidad moral y la graduación militar del general romano al que se dirigen, pero en ningún momento pretenden hablarle como caballeros o patricios representantes de su pueblo, sino sólo como simples habitantes de Numancia. El personaje numantino actúa en este contexto como un signo de humildad colectiva que carece de identidad individual:

Numancia, de quien soy ciudadano, ínclito general, a ti me envía.

[I, 233-234]

En la acotación inicial de la jornada segunda de la Numancia, que reproducimos a continuación, a propósito del «nombre propio» del personaje teatral, se observa en la presentación de los "gobernadores de Numancia» una relación inicial de igualdad entre sus distintos miembros, en la que no subyace ningún tipo de estructura aristocrática o estamental. Así es que la mayoría de los personajes que aparecen en la Numancia carecen de nombre propio, y adquieren únicamente denominaciones de valor genérico (numantino primero, numantino segundo, mujer primera, mujer segunda, madre, hijo, sacerdote, embajador... ${ }^{9}$. Así lo confirma la acotación inicial de la segunda jornada ${ }^{10}$ :

E. RILEY ha reiterado oportunamente a propósito de los personajes del Quijote, y que en efecto no está de más recuperar en el contexto de la Numancia; se trata del hecho que, frente a las exigencias clásicas del decoro, supuso la aparición del cristianismo, desde el que se propugnaba insistentemente que los más humildes habían de ser los más altos, y que todos los seres humanos eran, sólo espiritualmente, iguales, lo que en cierto modo equivalía a no considerar, al menos momentáneamente, las diferencias materiales y sociales. Cfr. E. AuERBACH, Mimesis. Dargestellte Wirklichkeit in der abendländischen Literatur. Berna, A. Francke AG Verlag, 1942. Trad. esp. de I. VIllanueva y E. IMAZ, Mimesis. La representación de la realidad en la literatura occidental. México, FCE, 1950; reed. 1987.

9 "Su mera denominación, pues - comentan al respecto F. Sevilla y A. Rey Hazas-, los define ya como partes del todo indisoluble que es Numancia. Los personajes con nombre propio, por otro lado, tampoco están excesivamente individualizados, puesto que encarnan una serie de funciones dramáticas imprescindibles para que la colectividad parezca auténtica y adquiera vida con caracteres de realidad» (cfr. F. Sevilla y A. Rey HazAs (eds.), Obra completa, vol. III, La Numancia de Miguel de Cervantes. Madrid, Alianza Editorial., 1996, p. xiii).

10 En este contexto, Teógenes representaría el poder político, y desempeñaría funcionalmente el papel de «rey», algo que nunca se explicita en la obra, pues to- 
Teógenes y Corabino, con otros cuatro numantinos, gobernadores de Numancia, y Marquino, hechicero, y un cuerpo muerto, que saldrá a su tiempo. Siéntanse a consejo, y los cuatro numantinos que no tienen nombres se señalan así: Primero, Segundo, Tercero, Cuarto.

\subsection{La "hybris" y los seres inocentes}

No se advierte en la acción de los numantinos, como sujetos de la experiencia trágica, un yerro o una falta moral grave (hybris) que explique el sufrimiento trágico que padecen ${ }^{11}$. No parece, pues, que se cumpla en esta tragedia la exigencia aristotélica, desde el momento en que el personaje que sufre es completamente inocente: «Es evidente que ni los hombres virtuosos deben aparecer pasando de la dicha al infortunio, pues esto no inspira temor ni compasión, sino repugnancia; ni los malvados, del infortunio a la dicha, pues esto es lo menos trágico que puede darse, ya que carece de todo lo indispensable, pues no inspira simpatía, ni compasión ni temor; ni tampoco debe el sumamente malo caer de la dicha en la desdicha, pues tal estructuración puede inspirar simpatía, pero no compasión ni temor, ya que aquélla se refiere al que no merece su desdicha, y

dos los personajes se mueven en el ámbito de una condición humilde, que ninguno trata de superar. No es un problema social o estamental el problema de la tragedia Numancia, sino un problema personal: la negación de la libertad como negación de la vida. Por su parte, Marquino representaría el poder religioso; su suicidio, tras verificar con el cuerpo muerto el destino trágico de Numancia, constituye una prolepsis o antecedente de cuanto va a suceder posteriormente a la colectividad de sus conciudadanos. Corabino, como miembro del consejo de gobernantes, representa el prototipo del valor militar; Morandro y Lira encarnan la experiencia amorosa en la experiencia trágica, del mismo modo que Morandro y Leoncio representan la pervivencia de la amistad en el seno de la tragedia humana. Finalmente, Viriato individualiza y confirma la voluntad íntegra del sacrificio numantino. Todos ellos son personajes que, sin sustraerse en absoluto de su condición humilde, se convierten, frente a los dictámenes tradicionales del decoro, en protagonistas decisivos de la experiencia trágica. Parece claro, desde el punto de vista de nuestra argumentación, que "la actitud de Cervantes - y coincidimos en esta observación con A. Hermenegildo- no fue ajustar el teatro a las reglas de Aristóteles ni imitar a los clásicos» (cfr. HERMENEGILDO, "El teatro trágico de Cervantes», La tragedia en el Renacimiento español. Barcelona, Planeta, 1973, pp. 367-386; p. cit. 368). En la misma línea se sitúan las interpretaciones, entre otros, de J. CANAVAGGIO: "¿Fue por lo tanto Cervantes un clasicista empedernido, aferrado a los preceptos aristotélicos? No hay por qué pensarlo: fuera de que en España no se respetaron aquellas reglas hasta el siglo XviII" (cfr. J. CANAVAgGio (ed.), Los baños de Argel. Pedro de Urdemalas de Miguel de Cervantes. Madrid, Taurus, 1992, p. 14).

"Como recuerda A. Hermenegildo, a propósito del arte trágico de C. de Virués - pensemos, por ejemplo, en La tragedia de la cruel Casandra- y otros contemporáneos de Cervantes, "la bondad de ciertas figuras va atada irremediablemente a su condición de víctimas inocentes» (cfr. HERMENEGILDo (ed.), El teatro español del siglo XVI. Del palacio al corral. Madrid, Biblioteca Nueva, 1998, p. 83). 
éste, al que nos es semejante; la compasión, al inocente, y el temor, al semejante; de suerte que tal acontecimiento no inspirará ni compasión ni temor» (Aristóteles, Poética, 1452b 34-1453a 7) ${ }^{12}$.

En efecto, Escipión es un personaje que está caracterizado inicialmente por una celebridad y una dignidad morales muy destacadas, desde las que dispone una nueva organización en la vida militar de su ejército:

Primero es menester que se refrene el vicio que entre todos se derrama; que si éste no se quita, en nada tiene con ellos que hacer la buena fama. Si este daño común no se previene, y se deja arraigar su ardiente llama, el vicio solo puede hacernos guerra más que los enemigos desta tierra.

$$
\text { [I, 41-48] }
$$

Sin embargo, a medida que avanza la acción, el carácter de Escipión se torna cada vez más inhumano, decepcionante y mediocre. Su presunta magnanimidad hace oídos sordos a la propuesta de paz y de justicia solicitada por los numantinos; se entrega en el uso de la fuerza bélica a actitudes maquiavélicas (S. Zimic) ${ }^{13}$, en las que domina la astucia del pillo frente a la celebridad del militar que combate valerosamente; y al final, frente a Viriato, con tal de mostrar ante la Roma imperial que ha podido capturar con vida al menos a un numantino, llega a sobornar al muchacho prometiéndole todo tipo de riquezas.

Cuando los embajadores numantinos presentan a Escipión una propuesta de convivencia pacífica, a cambio de tolerancia por par-

12 Según Aristóteles, la piedad sólo puede inspirarla la inocencia de aquellos caracteres que, siendo moralmente buenos, caen inmerecidamente en la desdicha y el infortunio. A su vez, el concepto de hybris se identifica más bien con el hecho de cometer una falta o error moral, por parte de un personaje "intermedio" o mediocre por su carácter. Desde este punto de vista, el exceso o hybris de la Numancia está presente más bien en la acción de Escipión, al rechazar, sin fundamentos dignos de un mandatario magnánimo, la propuesta de paz de los numantinos. Escribe Aristóteles: «Queda, pues, el personaje intermedio entre los mencionados. Y se halla en tal caso el que ni sobresale por su virtud y justicia ni cae en la desdicha por su bajeza o maldad, sino por algún yerro, siendo de los que gozaban de gran prestigio y felicidad [...]. Necesariamente, pues, una buena fábula [...] no ha de pasar de la desdicha a la dicha, sino, al contrario, de la dicha a la desdicha; no por maldad, sino por un gran yerro, o de un hombre cual se ha dicho, o de uno mejor antes que peor» (ARISTóteles, Poética, 1453a 7-16). En la Numancia cervantina, el hombre que, en todo caso, cumple con los requisitos señalados por Aristóteles es Escipión.

13 Cfr. El teatro de Cervantes. Madrid, Castalia, 1992. 
te de los mandatarios romanos, el general romano rechaza toda forma de paz que no resulte de un enfrentamiento bélico, tras el cual los numantinos acepten la voluntad de Roma, y le proporcionen, como jefe de las tropas victoriosas, la celebridad que pretende para su trayectoria militar. La respuesta de Escipión es concluyente, y no admite continuidad alguna en el diálogo, al rechazar el mensaje numantino, así como cualquier posibilidad de comunicación con el enemigo:

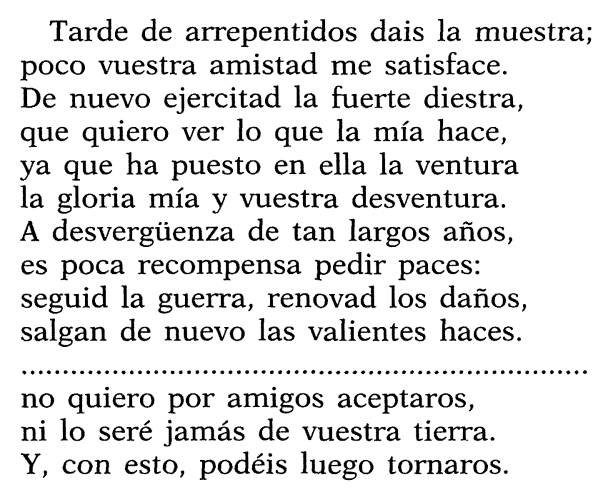

[I, 269-276 у 299-301]

Incurre aquí Escipión en lo que podría denominarse pecado de hybris o error moral, según la concepción de la tragedia antigua, por el que el personaje que detenta el poder en un momento dado comete una desmesura o exceso de consecuencias irreversibles. De este modo, el personaje se devalúa moralmente, se torna mediocre, pierde instantáneamente la altura moral que se espera de él, e incurre en un error, en una falta que, de haberse evitado, habría evitado la tragedia. Así lo hace constar Corabino al propio Escipión: «Mal con tu nombradía correspondes, / mal podrás deste modo sustentalla» (III, 1203-1204). Sin embargo, al contrario de lo que esperaríamos de un planteamiento genuinamente helénico de los hechos, en la Numancia no será Escipión quien reciba las consecuencias más graves del hecho trágico, sino los numantinos, es decir, aquellos que no han incurrido en ningún acto, exceso o falta moral, que les haga responsables directos del infortunio de padecer la agresión romana. En consecuencia, el rechazo de Escipión a toda forma de entendimiento pacífica, y su respuesta negadora de posibilidades de convivencia, enaltece la dignidad numantina, y justifica su actitud, a la vez que atenúa en el militar toda nobleza de ánimo, en favor de liberalidad y tolerancia. 
$\mathrm{Y}$, pues niegas la paz que con buen celo te ha sido por nosotros demandada, de hoy más la causa nuestra con el cielo quedará por mejor calificada.

$[\mathrm{I}, 281-284]^{14}$

\subsection{El heroísmo de los plebeyos}

La Numancia es una tragedia, quizá la primera en la historia de la dramaturgia occidental, que confiere honor y dignidad a la acción heroica de personajes humildes. Cervantes expresa y justifica el honor de los villanos, en una de las experiencias más radicales de la existencia humana, como es la decisión del sacrificio colectivo, la autoinmolación de una ciudad. El reconocimiento del honor en los villanos era algo muy teatralizado en las comedias de Lope; recuérdese el caso de Fuenteovejuna, donde el comendador Fernán Gómez desafía a los villanos negándoles precisamente esta cualidad: «¿Vosotros honor tenéis?» (II, 986).

Nada hace pensar que el tratamiento del honor que presenta Cervantes en la Numancia se relacione estrechamente con los códigos e imperativos de la honra característicos de la "comedia nueva»; el honor de los numantinos no se agota ni se explica en sí mismo, sino que es preciso considerarlo desde la perspectiva trágica en que se sitúa la acción de sus protagonistas. La dignidad y el honor de los habitantes de Numancia no adquiere ni pretende en ningún momento representatividad social o fundamento estamental; no subyace en esa concepción de la honra ninguna estructura de clase. El honor se percibe aquí como un atributo de la libertad, y como una consecuencia, antes que una causa, de la voluntaria decisión de inmolarse colectivamente. El objetivo de los numantinos es la conservación de la libertad, a la que no renuncian jamás, así como la preservación del honor, como legitimidad o coherencia moral que garantiza la integridad de sus valores, a la vez que ase-

14 Los versos 2342-2351, en que Escipión promete a Viriato grandes riquezas a cambio de que se le entregue, de modo que el general conserve su honor y su prestancia a los ojos de Roma, constituyen acaso una expresión poco decorosa de un militar cuya fama responde, como se nos sugiere inicialmente, a la grandeza moral, el valor bélico y la honradez en la victoria. El discurso de Escipión es momentáneamente el de un sobornador, que trata de comprar a toda costa, en cuerpo y alma, al único numantino con vida, con objeto de mantener una celebridad que su conducta a lo largo de la tragedia ha desmitificado en diversos momentos. Una vez más la actitud de Escipión sumerge al personaje en un grado superior de mediocridad, que contrasta con el valor y la integridad de su pueril adversario. Escipión soborna infructuosamente a Viriato con una promesa de libertad y de riqueza que, antes que imposible o verosímil, resulta indecorosa. 
gura la convivencia. La conservación impoluta de tan altos ideales exige, todavía en la Edad Moderna, desde la mentalidad de Miguel de Cervantes, un desenlace trágico, cuyos hechos ponen a prueba el heroísmo verosímil, no de altos patricios o aristócratas, que hayan podido incurrir más o menos conscientemente en faltas morales, sino de gentes singularmente humildes y completamente inocentes.

\subsection{Cuando dioses y númenes no intervienen en la fábula...}

El valor del destino y de las fuerzas supranaturales se encuentra en la Numancia formalmente referido, pero funcionalmente muy atenuado. Las invocaciones al mundo metafísico y suprasensible desempeñan en la tragedia un valor emotivo, formal o retórico, antes que discursivo o funcional; el resultado de las experiencias agoreras y adivinatorias no influye decisivamente en el curso de los acontecimientos ni en las decisiones de sus protagonistas. Más tienen a veces de escenas costumbristas que de hechos auténticamente reveladores de las secuencias funcionales de la acción ${ }^{15}$.

15 Desde este punto de vista, autores como F. Sevilla Arroyo y A. Rey Hazas confieren al honor un valor funcionalmente muy superior en el discurso de la Numancia al que adquiere el tratamiento del destino y sus supuestos imperativos metafísicos: «Se trata, pues, de una cuestión de honor colectivo, vista desde la perspectiva histórica de los años finales del siglo XVI español. Ahora bien, lo cierto es que el hado que amenaza la urbe de los arévacos era completamente nefasto, y que el vaticinio de Marquino había predicho la muerte de los numantinos a manos de ellos mismos, tal y como acaece, a la postre. Entonces, ¿qué fuerza predomina, la del sino o la del honor? ¿Se impone un móvil a otro? ¿Confluyen, sin más, el destino y la libertad honrosa? La cuestión es compleja, sin duda. En principio, parece que los dos motores básicos de la acción trágica se hermanan sin dificultad, puesto que la predicción del fatum coincide con la única salida honrosa que tienen los habitantes de la ciudad sitiada. Y así es, si analizamos únicamente el final de la obra, si enfocamos el problema sólo desde su resultado último. Pero no sucede lo mismo cuando estudiamos el proceso dramático en su conjunto, porque, de hecho, los numantinos, antes de conocer los agüeros, plantean las mismas decisiones que toman después de saberlos, y ponen su objetivo en saber exclusivamente qué tipo de muerte comporta más honor para ellos. Nada más. La honra, libremente elegida, es, en suma, la fuerza motriz decisiva que les impulsa a la autoinmolación. Si ello coincide con su destino, quiere decir que, como defendía Leoncio, los numantinos han sido capaces de superarlo con su valor, su fuerza y su voluntad libre; más aún, que han superado su adverso sino de la única manera posible, esto es, asumiendo su carácter inapelable en beneficio propio, como hacían los grandes héroes trágicos de la antigüedad, en bien de su honor, de su libertad y de su victoria. En consecuencia, si tuviéramos que jerarquizar ambos móviles de la acción dramática, diríamos que el principal motor trágico de La Numancia cervantina es el honor colectivo, más que el hado hostil, dado que su elección es libre, aunque coincida con el destino en el resultado final» (cfr. F. SEvilla y A. Rey Hazas (eds.), 
Son numerosos los momentos en los que, a lo largo de la Numancia, se alude a una realidad trascendente en la que no se identifica ni reconoce de forma explícita un poder superior, capaz de intervenir funcionalmente en el curso de los acontecimientos y acciones humanas ${ }^{16}$.

El propio Escipión, en su arenga a los soldados romanos, advierte, con claridad sorprendente para la época, que la fortuna nada tiene que ver con el desenlace del enfrentamiento que mantienen contra los numantinos, sino que es más bien el poder de la voluntad humana, la diligencia frente a la pereza ${ }^{17}$, lo que ha de determinar, en el cerco de Numancia, el triunfo o la derrota de las tropas romanas. Incluso se llega a afirmar algo semejante a que cada ser humano es en cierto modo dueño de su propio destino, desterrando así la influencia de una realidad metafísica en el desarrollo de los asuntos humanos:

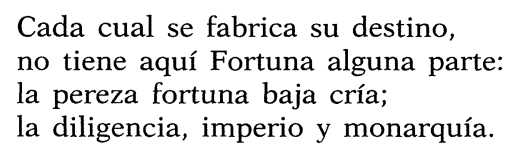

$$
\text { [I, 157-160] }
$$

Como sucedía en la mayor parte de las religiones del mundo antiguo, politeísmo y antropomorfismo son las cualidades básicas que definen el conjunto de divinidades invocadas por los numantinos. Al igual que en la Grecia clásica, los dioses de Numancia no proyectan sobre el mundo un programa teológico, ni se muestran dispuestos a juzgar a la humanidad destinándola hacia una salva-

Obra completa, vol. III, La Numancia de Miguel de Cervantes. Madrid, Alianza Editorial., 1996, pp. xiv-xv).

16 Una de las cualidades de la tragedia antigua consistía en presentar ante el espectador la experiencia trágica en toda su desnudez; en ella hacían acto de presencia recurrente los impulsos religiosos, los conflictos espirituales, la manifiesta injerencia de los dioses (deus ex machina), etc., frente a las circunstancias que caracterizan la tragedia moderna, en la cual la inferencia metafísica se muestra mucho más atenuada: «El individuo es obligado a refugiarse en sí mismo. Aparece la desesperación, se plantean preguntas desesperadas por el sentido, el fin y la naturaleza de los dioses. Los lamentos y las acusaciones saltan a primer plano. En algunos momentos parece hacerse sentir la paz de la oración, de la razón divina, para volver a desaparecer enseguida acosada por nuevas dudas. Ya no hay redención alguna. Los dioses son sustituidos por la tyché. Los límites y soledad del hombre se manifiestan de modo espantoso" (K. JASPERS, ob. cit., p. 90).

17 Sin duda la imagen de Marte a la que aquí alude Escipión preludia la pintura de Velázquez, en la que el dios de la guerra desmiente, con tu actitud distendida y abandonada, la expresión de cualquier acto heroico: «La blanda Venus con el duro Marte / jamás hacen durable ayuntamiento / [...] hállase mal el trabajoso marte» (I, 89-90 y 154). 
ción o condenación post mortem; es más, ni tan siquiera están presentes - a diferencia de la literatura helénica - en el desarrollo de la acción humana, encarnada en los personajes, con objeto de subrayar o intensificar su importancia. De los dioses numantinos podemos decir tan sólo que simplemente son evocados o consultados. De los elementos esenciales que configuran la imagen de una divinidad —nombre, iconografía, mitología y culto—, los numantinos apenas nos proporcionan detalles. Los dioses y númenes que presenta Cervantes en la Numancia son, antes que agentes o co-protagonistas de la acción, destinatarios mudos - a veces también imperceptibles- de un diálogo en el que sólo intervienen interlocutores humanos.

En la escena segunda de la jornada II de la Numancia, las señales y agüeros son interpretados inmediatamente como signos inequívocos de fracaso numantino. Sin embargo, esta lectura de los augures, indicativa del desenlace trágico, se interpreta no como un hecho inevitable, por imperativo de los dioses, sino como consecuencia de la superioridad material del ejército romano. Los dioses no se presentan como mandatarios de una realidad trascendente, sino como intérpretes, o intermediarios reveladores, de sus secretos; diríamos incluso que los dioses desempeñan en la Numancia una «función hermenéutica»: «que Júpiter soberano / nos descubrirá el camino» [II, 773-774]. Júpiter asume, pues, las funciones de Hermes. Su alta divinidad desciende reveladoramente, en la tragedia cervantina, a los límites de la percepción humana.

\footnotetext{
¿No miras cómo el humo se apresura a caminar al lado del poniente, y la amarilla llama mal sigura sus puntas encamina hacia el oriente? ¡Desdichada señal! ¡Señal notoria que nuestro mal y daño está presente!

¡Mal responde el agüero: mal podremos ofrecer esperanza al pueblo triste, para salir del mal que poseemos!
}

[II, 816-842]

Percatado de los funestos augurios, el pueblo numantino no se revela ante los númenes, simplemente comunica entre sus conciudadanos el resultado de los oráculos, que asume con inquietud y resignación. Numancia no exige del poder de los dioses un cambio en el destino, pues no hay clemencia posible al no haber solución posible, ya que ante el poder romano, real y efectivamente existente, poco puede hacer el poder numinoso. Tal parece ser el mensaje 
de Cervantes en esta tragedia. Los dioses no pueden ayudar a los numantinos; los númenes no sirven al hombre. En este sentido, es la de Cervantes una tragedia profundamente humana, y por ello mismo, moderna. Hombres luchan contra hombres, sin intermediarios ni aliados divinos, en una guerra laica. Se observará una vez más que el cerco de Troya no es el cerco de Numancia. Una característica esencial del mundo homérico, es decir, de buena parte de la literatura de la Edad Antigua, consistía en hacer de la acción, y de sus episodios más significativos, una fábula cuyo resultado dependía de una intervención divina y de una responsabilidad humana. Desde el punto de vista de la poética, la Numancia cervantina se distancia de la primera de estas exigencias: los dioses son simplemente divinidades a las que se atribuyen agüeros en los que creen - o no creen - los personajes de la tragedia, pero en ningún momento los númenes intervienen directa o individualmente en el poema, ni de obra ni de palabra. Sin duda su silencio es, en la concepción cervantina de un mundo trágico, mucho más expresivo que su verbo. En la modernidad es central el problema de la secularización: es época de dioses huidos. Aquí radica, sin duda, una más de las cualidades que hacen de la Numancia una de las primeras tragedias de la modernidad, al proponer una concepción del hecho trágico profundamente diferente a la exigida por la poética antigua. La existencia humana no está ya determinada por una realidad metafísica.

\subsection{La voz de la mujer y la coralidad del personaje alegórico}

El discurso de las mujeres de Numancia desmiente y desmitifica la secular visión masculina del heroísmo épico y trágico, a la vez que exige la presencia de la mujer en la expresión dignificante del dolor y el sufrimiento del ser humano. Las numantinas no pretenden llorar, desde la supervivencia humillada, y a manos del enemigo, cual Andrómaca o Hécuba, la muerte de sus varones. Se observa una vez más que entre los numantinos no existen diferencias de ningún tipo, que obedezcan a criterios sociales, morales, estamentales, o sexuales. Así se distribuyen por igual, entre los miembros de la ciudad, los únicos alimentos de que disponen: «y, sin del chico al grande hacer mejora, / repártanse entre todos...» (III, 14381439). La piedad y el terror, como sentimientos que son consecuencia de situaciones extremas, tienden a disipar las diferencias entre los seres, y a identificar en una sola experiencia diferentes impulsos humanos. 
La voz de la mujer está dotada en la Numancia de atributos corales y funcionales. El hombre no está solo en la tragedia numantina, y no decide en soledad el curso de los hechos. La voz de sus esposas cambia razonablemente el desarrollo de la acción. En el teatro de Cervantes la palabra de la mujer parece más importante en la evolución de la fábula que la influencia del destino con todos sus hados. Por un lado, el hombre escucha a la mujer, por otro, numantinos como Leoncio niegan todo el valor de los augurios. En consecuencia, Teógenes, el sabio gobernante de la ciudad, decreta que «jamás en vida o muerte os dejaremos; / antes, en muerte y vida os serviremos» (III, 1408-1409). El discurso de la mujer convence, se le presta atención y reconocimiento, y en adelante "sólo se ha de mirar que el enemigo / no alcance de nosotros triunfo o gloria» (III, 1418-1419). La voz de la mujer se diferencia ahora de las voces del coro ático; en la tragedia griega el coro no intervenía en el curso de la fábula, no determinaba la evolución o el desarrollo de los hechos; acompañaba coralmente el discurso de los grandes interlocutores, atemperaba el pathos, confirmaba las razones de los hablantes y aconsejaba prudencia; en suma, desempeñaba una función emotiva, mas nunca discursiva o funcional, y en absoluto con capacidad de intervención en la metabolé de la fábula.

A las figuras alegóricas de la Numancia se les han atribuido diferentes funciones: en primer lugar, asumirían cualidades en cierto modo equivalentes a las del coro en la tragedia antigua ${ }^{18}$; por otro lado, desde una perspectiva metateatral, se ha tratado de identificar en el personaje coral una especie de espectador privilegiado de la tragedia; se las ha considerado también como personajes que, con su percepción del drama, contribuyen a un enriquecimiento de la recepción del espectador, mediante la exposición de hechos y argumentaciones sobre situaciones futuras, de modo que ofrecerían una interpretación del texto que actuaría a su vez sobre la interpretación de los espectadores reales (transducción) ${ }^{19}$; en este sentido, introducirían una estructura perspectivística en la dramaturgia cervantina, alcanzando de este modo ciertos efectos polifónicos en el uso del lenguaje; finalmente, hay que reconocer que los persona-

18 Como se ha repetido con frecuencia, los personajes alegóricos de la tragedia cervantina desempeñan funciones semejantes al coro trágico griego: informan de lo que sucede fuera de la escena, explican acciones, revelan estados de ánimo, estimulan emociones, derivan conclusiones, profetizan, etc.; muestran siempre una función emotiva, jamás discursiva o funcional, a la vez que disponen de una triple capacidad épica, reflexiva y dramática.

${ }_{19}$ Cfr., sobre el concepto de transducción, nuestro trabajo sobre La expresión dialógica en el discurso lírico (Pragmática y transducción). Kassel, Reichenberger, 1994. 
jes alegóricos se sitúan en cierto modo en un ámbito de trascendencia en el espacio y en el tiempo de la tragedia. Representan una realidad trascendente, a la que remiten, y a través de la cual se sitúan por encima de los hechos genuinamente humanos de la experiencia trágica. Los personajes alegóricos suplen en cierto modo la ausencia de personajes nobles, de figuras próximas al mundo elevado y aristocrático que postulaba - pensemos en la Ilíada y en la literatura antigua- una realidad trascendente, con la que incluso convivían los más selectos de los personajes, y sin la cual quizás la Antigüedad no podría haber llegado a concebir plenamente el espíritu de lo trágico.

El modo cervantino de emplear los parlamentos corales de los personajes alegóricos permite establecer relaciones de semejanza con el uso que de los coros hacen Eurípides y Séneca ${ }^{20}$ : suele interpretar la acción desde principios morales o filosóficos; en muchos casos acude a paradigmas mitológicos o legendarios; se sitúa en la perspectiva de un oyente o espectador que traslada a un plano ideal aquello que percibe en la acción de los personajes; las intervenciones corales tienden a situarse entre actos, como intermedios líricos de reflexión sobre la acción trágica; y entre los temas tratados figuran algunos de los más característicos de la tragedia senequista (brevedad de la vida, riqueza y poder como fuente de desgracias, ambición, crueldad, inestabilidad de todo lo humano, etc...).

\subsection{El espacio trágico}

En el cuadro segundo de la jornada segunda de la Numancia tiene lugar una escena, la de los augurios, que puede considerarse como ejemplo de teatro en el teatro. El pueblo numantino, y concretamente los personajes de Morandro y Leoncio, acude al sacrificio y ritual que se ofrece a los dioses con objeto de conocer cuál será el destino de Numancia. El pueblo asiste como espectador a la contemplación de un ritual trágico, un sacrificio a los dioses, en el seno de la acción principal de la tragedia. La acotación que indica funcionalmente la composición y actuación de la comitiva resulta por sí misma suficientemente expresiva, pues dispone los

20 Las únicas diferencias observables entre el autor griego y el romano atañen a la forma métrica (vid. F. Rodríguez ADRADOS, Fiesta, comedia y tragedia. Madrid, Alianza, 1983). En Eurípides el coro no interviene nunca directamente en la acción; y lo mismo sucede en las tragedias de Séneca, con las excepciones de Las Troyanas (vs. 67-164), Agamenón (vs. 586-781) y Hércules en el Eta (vs. 104-232), donde el coreuta sí interviene con valor funcional en el desarrollo de la fábula. 
mecanismos necesarios para representar la teatralización del sacrificio dentro de la teatralización de la tragedia:

\footnotetext{
Han de salir agora dos Numantinos, vestidos como sacerdotes antiguos, y traen asido de los cuernos en medio de entrambos un carnero grande, coronado de oliva o yedra y otras flores, y un Paje con una fuente de plata y una toalla al hombro; Otro, con un jarro de plata lleno de agua; Otro, con otro lleno de vino; Otro, con otro plato de plata con un poco de incienso; Otro, con fuego y leña; Otro que ponga una mesa con un tapete, donde se ponga todo esto; y salgan en esta scena todos los que hubiere en la comedia, en hábito de numantinos, y luego los Sacerdotes, y dejando el uno el carnero de la mano, diga: «Señales ciertas de dolores ciertos...» [II, 789].
}

La experiencia trágica de la Edad Moderna se aleja de la inferencia metafísica de la Antigüedad, la recuerda y reproduce, pero le resta valor. Leoncio y Morandro la contemplan como quien contempla un espectáculo teatral. Por si quedan dudas, la secuencia de los augurios se reitera con el protagonismo de Marquino y la presencia sobrenatural del cuerpo muerto. La invocación del poder metafísico y de la posible voluntad de sus designios frente a la existencia humana constituye en la Numancia cervantina un hecho que es objeto de representación teatral para los propios numantinos; el espectador del siglo XVI, como el del siglo XXI, se siente doblemente distanciado, merced a la concepción teatral de Cervantes, de la experiencia dominante de un poder moral trascendente y metafísico, cada vez más lejano en el tiempo de la historia, así como convencionalmente más distante en el espacio de la representación teatral. Un doble escenario separa en el teatro cervantino al espectador de los númenes.

Aunque todo espacio es susceptible de resultar propicio a la experiencia trágica, no es imprescindible, en principio, que esta categoría haya de participar esencialmente en el desarrollo de la acción: basta con que diseñe, y circunscriba en todo caso, el escenario en que ha de tener lugar la fábula. Sin embargo, el espacio de la Numancia adquiere consecuencias inmediatas y esenciales en la experiencia trágica, al transformar al protagonista en un eterno prisionero. El espacio de la tragedia delimita las posibilidades de acción y de existencia de los personajes, y hace que precisamente su existencia carezca de sentido fuera del espacio en el que se les sitúa: pueden abandonar la espacialización que se les adjudica - no jerarquizada, al contrario de lo que sucedía en la tragedia clásica-, pero no sin arriesgar radicalmente su vida, y renunciar de este modo a la experiencia de su existencia.

Jesús G. Maestro Universidad de Vigo 